\title{
Urban waste collectors in Belo Horizonte, Brazil; their perceptions of occupational health risk
}

Shortened title: Risk perceptions of urban waste collectors

Marcos Paulo Gomes Mol ${ }^{[1]}$, Sandy Cairncross ${ }^{[2]}$, Dirceu Bartolomeu Greco ${ }^{[3]}$ and

Leo Heller ${ }^{[4]}$

[1]. Diretoria de Pesquisa e Desenvolvimento, Fundação Ezequiel Dias, Belo Horizonte, MG, Brasil. [2]. Department of Disease Control, London School of Hygiene and Tropical Medicine, London, England.

[3]. Faculdade de Medicina, Universidade Federal de Minas Gerais, Belo Horizonte, MG, Brasil.

[4]. Centro de Pesquisas René Rachou, Fundação Oswaldo Cruz, Belo Horizonte, MG, Brasil.

Corresponding author contact details:

Dr. Marcos Paulo Gomes Mol. Fundação Ezequiel Dias, Diretoria de Pesquisa e Desenvolvimento. Rua Conde Pereira 80, Bairro Gameleira. Belo Horizonte/MG. Brazil. CEP 30510-010. +55 31 3314-4950. marcos.mol@funed.mg.gov.br

\begin{abstract}
Frequent contact with hazardous materials makes waste collection a potentially unhealthy activity. This article assesses the perception of waste management workers regarding work-related accidents in domestic and health service contexts in Brazil. Six focus groups were performed between June 2014 and August 2015. The aims of this study were to apprehend different aspects of the participants' health, workers' experiences of workrelated accidents and perception of risks. Cuts and puncture injuries were reported most frequently in the line of work and were often considered as irrelevant. Immunization against hepatitis B was not common among all workers, which increases the risk of infection for those individuals. Finally, it is considered urgent to consolidate an inclusive space in which workers can have discussions on their health.
\end{abstract}

Keywords: Risk, Occupational Health, Accident, Waste Collectors 


\section{Background}

The profession of collecting solid waste, be it household or healthcare waste, presents a potential situation of risk for the workers involved. Several studies have revealed that frequent contact with hazardous substances puts the health of such workers at risk (Ferreira \& Anjos, 2001; Rushton, 2003; Oliveira, 2007; Domingo \& Nadal, 2009).

Collecting solid waste presents a risk of accidents with perforating or cutting materials ("sharps"), which, in some cases, entail contact with infected blood or bodily fluids. Moreover, solid waste is often collected within a fast, high-pressure atmosphere. This makes risk of accident greater and provokes problems in musculature and the vertebrae (Velloso, Santos \& Anjos, 1997; Silva, Sperling \& Barros, 2014).

The risks observed in the process of solid waste collection have been categorized as: physical, chemical, ergonomic, mechanic, biological and social. The possible dangers related to physical risks are related to noise, odors, dust and sharps, which can cause effects including general discomfort, nausea, hearing loss, hypertension, respiratory problems and cuts. The presence of heavy metals, medication and other toxic substances (carcinogens, teratogens or mutagens, explosives, irritants or noxious substances, oxidants, and corrosive or inflammable materials) and associated chemical risks can potentially poison the worker. Biological risks are characterized by the presence of fungi, viruses and bacteria, which are common in domestic and healthcare waste. Mechanical and ergonomic risks are associated with workers' repeated efforts during their activities, which can affect their musculoskeletal system (Ferreira \& Anjos, 2001; Velloso et al., 1997; Thomas, 2000). 
From a legal perspective, Brazil's Constitution (Constituição Federal Brasileira) ensures the right of urban workers to reduce inherent workplace risks through health, hygiene and safety standards (Brasil, 1988). Furthermore, Annex 14 of regulation NR 15 (Decree $\mathrm{n}^{\circ}$ 3.214/1978 of the Ministry of Work and Employment) designates the collection and industrialization of urban solid waste as an activity that reaches the maximum degree of unhealthy conditions, without distinguishing the type of solid waste that is collected.

Accidents with needles and other sharp objects used in healthcare activities are associated with the occupational transmission of more than 20 different pathogens. Among them, the viruses hepatitis $\mathrm{B}$ and $\mathrm{C}$ (HBV and $\mathrm{HCV}$ ) and human immunodeficiency virus (HIV) have been frequently associated with accidents involving this type of waste (Tarantola, Abiteboul \& Rachline, 2006; Stehling, 2013).

Exposure to the danger of cuts and needlestick injuries through occupational contact with solid waste was discussed by Veloso et al. (1997), where 67 accidents were identified of which $50.7 \%$ were clinically diagnosed as cuts or wounds. Another study of professionals in domestic waste collection, performed in Bangkok, Thailand, indicated that $77.4 \%$ of accident reports involved needles or other sharps (Luksamijarulkul, Sujirarat \& Charupoonphol, 2008). Other similar studies confirm the high risk of this type of accident associated with solid waste collection (Ferreira \& Anjos, 2001; Domingo \& Nadal, 2009; Silva et al., 2014; Lazzari \& Reis, 2011).

Currently, there are approximately 600 urban solid waste workers and 150 healthcare waste workers, formal employed exclusively associated to external collection, i.e., outside generational places (domicile or organizations), in Belo Horizonte city (2.5 million population), Brazil. Personal protection equipment (PPE) usually adopted by these workers include boots, gloves, uniforms and eventually masks. There are few 
differences between PPE adopted to domestic waste workers and healthcare waste workers. Public health professionals, according to Gebbie et a., (2002), should have professional skills including use of appropriate personal protective equipment. The same idea must be applied to waste workers, corroborating the theory of protecting health at work.

According to Brazilian legislation about occupational safety, Regulatory Standard MTE 191/2008, employers should provide PPE to their employees, and ensure their correct use. Failure complying occupational regulations makes employer subject to infractions and penalties applied, around USD 180 until USD 980,000.

Many studies was conducted around labor activities and their negative health consequences around waste collection (Corrao et al., 2013; Domingo \& Nadak, 2009; Elder \& Paterson, 2006; Ferreira \& Anjos, 2001; Silva et al., 2014; Shiferaw, Abebe \& Mihret, 2011), nevertheless, few of them proposed to investigate in details the cause of injuries, the meaning of accidents and health from exposed subjects and, mainly, their perception about risks associated to their work. These considerations are extremely relevant in order to reveal a neglected situation of professionals acting in a completely unfavorable working condition.

Thus, the objective of this article is to study the perceptions of workers handling domestic and healthcare wastes in the city of Belo Horizonte, Brazil, regarding their work and the associated health risks. Emphasis was given to the associations made by workers between possible health-related interferences and their contact with solid waste. 


\section{Methodology}

Six focus groups were formed, three with workers collecting healthcare waste and three with workers handling domestic waste; all took place in the city of Belo Horizonte. The aim of the focus groups was to identify the perceptions of workers regarding the importance of their work, the inherent risks of handling solid waste, the potential health impacts, the precautions considered important in the course of their work, and the relationship between the cause of a work-related accident and the subsequent measures to be taken. The research categories originate from previous studies. Research focusing on risks to worker health by Velloso et al. (1997), Ferreira and Anjos (2001) and Domingo and Nadal (2009), has shown that the way in which the activity of collecting solid waste is carried out can increase the risks. The qualitative research was based on a semistructured interview guide created with consideration for the above-mentioned topics.

Two focus groups were organized in June 2014 as a pre-test for the proposed method. The remaining focus groups were held between June and August 2015. The data generated in the pre-test were incorporated into the overall analysis presented in this article, given the relevance of the information obtained. In TABLE 1, the groups and their participants are identified. 
TABLE 1 - Identification of the focus groups and their respective participants.

\begin{tabular}{|c|c|c|c|c|c|}
\hline $\begin{array}{l}\text { Type of waste } \\
\text { /Focus group }\end{array}$ & $\begin{array}{c}\mathbf{N}^{\circ} \\
\text { Participants }\end{array}$ & $\begin{array}{c}\text { Number of different } \\
\text { types of waste } \\
\text { collector }\end{array}$ & $\begin{array}{c}\text { Participant } \\
\text { gender }\end{array}$ & $\begin{array}{c}\text { Age - } \\
\text { mean (SD) }\end{array}$ & $\begin{array}{c}\text { Length of time } \\
\text { (years) working in } \\
\text { waste collection - } \\
\text { mean (SD) }\end{array}$ \\
\hline RSU-PT & 5 & $5 \mathrm{RSU}$ & $1(\mathrm{M}) ; 4(\mathrm{~F})$ & $33.2(7.2)$ & $10.4(6.3)$ \\
\hline RSS-PT & 8 & $8 \mathrm{RSS}$ & $2(\mathrm{M}) ; 6(\mathrm{~F})$ & $37.6(12.6)$ & $13.6(10.0)$ \\
\hline RSU-G1 / RSS-G1 & 5 & 2 RSU; 3 RSS & $3(\mathrm{M}) ; 2(\mathrm{~F})$ & $38.6(8.6)$ & $15.0(8.4)$ \\
\hline RSS-G2 & 8 & $8 \mathrm{RSS}$ & $8(\mathrm{M})$ & $36.2(10.5)$ & $9.6(7.6)$ \\
\hline RSU-G3 & 4 & $4 \mathrm{RSU}$ & $4(\mathrm{M})$ & $44.3(4.9)$ & $17.3(5.3)$ \\
\hline RSU-G4 & 4 & $4 \mathrm{RSU}$ & $4(\mathrm{M})$ & $33.5(6.5)$ & $8.3(4.4)$ \\
\hline
\end{tabular}

The groups were each composed of 4 to 10 individuals. Twenty individuals were invited to participate in each focus group, due to the possibility of withdrawals. Forty letters describing basic information about the methods was sent randomly to waste workers from Belo Horizonte city, some days before each focus group. All interested in participate was included. The discussions were recorded with the consent of all participants. The sessions were recorded to ensure that the maximum amount of the participants' contributions would be obtained; the audio information were completely written by transcription. The focus groups were performed in reserved rooms and, as far as possible, with seating arranged in a circle. Some meetings were performed with only four participants due to cancellation by previously invited individuals. The focus groups performed with four participants were close to the minimum number of participants recommended in the literature (Powell \& Single, 1996; Worthen, Sanders \& Fitzpatrick, 2004; Barbour, 2009; Gaskel, 2007).

The steps followed in conducting the focus groups followed the recommendations of Debus (1988) and Krueger (1998), including: opening, preparation, debate, closing, discussion and subsequent action. The research team comprised a moderator and two 
observers. The observers were responsible for recording the beginning of each participant's remarks and associating them with the respective participant. In this way, it was possible to transcribe the entire discussion and to register the participants' behavior at all times.

In order to identify the participants' remarks without revealing their names, each participant was given a badge marked with a numerical code. Each number corresponded with a chair. In this fashion, it was possible to associate the focus group and the specific number of each participant with all comments made. The code was structured in the following way: N-ACRONYM-G, where $\mathrm{N}$ represented the number attributed to the participant; ACRONYM corresponded to the type of solid waste to which the participants in a given focus group were exposed (RSS for healthcare waste and RSU for urban/domestic waste); and G corresponded to the focus group number; the pre-test was identified as PT.

Firstly focus groups were proposed divided by work activities, according to the type was wastes exposed (urban/domestic or healthcare wastes). One mixed group was proposed to understand more clearly how the participants would react when listening about different context of work conditions.

Creating an inclusive atmosphere made it possible to open up space for participants to share their opinions on the problems and difficulties of their profession, especially regarding the concepts of health and work-related risks. The interaction developed within the group allowed the participants to identify with the remarks of others. Shared meanings were voiced and, in several cases, a common sense was established. This confirmed that the visions expressed in a focus group must not be understood separately from the interaction; they are tied to the dialogue between the individuals and depend on the 
discussion in which they emerge (Barbour, 2009; Gaskel, 2007; Ivey, 2011; Krueger, 2006; Flick, 2009). Data analysis was performed via categorical content analysis (Bardin, 2008). The categories adopted were: perception of the participants' health; use of personal protective equipment; perspective regarding accidents suffered; perception of workassociated risks; prejudice for working with solid waste.

The evaluation was carried out from the transcripts of focus groups data, i.e. text corpus, allowing operations of dismemberment of the texts in units, according to the established categories. Two researchers read the transcripts and discuss about information notes before starting analysis process, aiming to represent real discussion done during focus groups. The broad purpose of analysis was to seek meaning and understanding (Bauer \& Gaskell, 2007; Bardin, 2008).

As a research project involving human subjects, this project followed the directives defined in Resolution $N^{\circ} 466 / 12$ of the National Health Council, and was approved by the Research Ethics Committee of the UFMG (file 28018714.6.0000.5149) before the commencement of activities. The participants were aware of the research project and those that agreed to participate signed an informed consent form [Termo de Consentimento Livre e Esclarecido - TCLE in Brazil (2015)] in which they authorized the use of their information in the research project.

\section{Results}

Results and discussion sections are presented according to main themes considered in focus groups: perception of the participants' health; use of personal protective equipment; perspective regarding accidents suffered; perception of work-associated risks; prejudice 
for working with solid waste. A compilation of the main themes expressed throughout the focus groups and some of the participants' remarks are presented in TABLE 2. 


\section{TABLE 2 - Participants' remarks according to the main themes discussed.}

\section{Theme addressed Participants' remarks}

\section{These days I've even had a sore back;}

For me, pain is normal. I take two "dorflex" (pain killers), I put on some cooling gel, get my gloves on and go to work. For me, it's normal.

Perception of participants' health

\section{Use of personal} protective equipmen

\section{Perspective on accidents} suffered

Here, there aren't a lot of people that have been with the company for a long time, you understand? So a given problem that could be caused by this rubbish could take years

Over time, our bodies get older and you don't have that protection, that medical oversight that there should be for the service that we provide. So our health just gets worse;

He contracted something, poked by a needle, in hospital waste (referring to hepatitis);

If there's hepatitis there (in the needle) and it pokes you, you'll get it;

Unfortunately, it's the default uniform, so we have to follow the company's rules. If this is the uniform, we can't change that. (An attitude of fear was mentioned by a participant in making a negative comment about the company);

The glove is really fragile in this area (remark that the gloves issued are inadequate for the work performed - fragile and insufficient protection for the skin.

I've already had one accident, but, thank God, the box, the needle wasn't contaminated. I had to do all these tests. I went through all the required processes, understand?

(...) it weighs 50, $60 \mathrm{~kg}$. He hurt his back, so they went and told him not to request leave, they didn't act in good faith with him. (...) They didn't give him a WAC, a Work Accident Communication form;

My finger will never be the same again, it was deformed. Some bacteria got onto my hand and I almost lost this finger. I had to have two surgical operations on my finger;

When they checked, I had broken my meniscus, it had broken so I had surgery, did physiotherapy. I think that, like, the company should have put up the money; With night staff, getting run over by cars is normal, a constant.

With cuts, it's most common. Most common accidents: cuts and needlesticks. (...) With the highest frequency. And sprains too. Some syringe can pop up in the rubbish that you aren't even expecting. And if it sticks you, you can get contaminated, it's very dangerous. (...) I already had an accident where I stayed on leave for 15 to 20 days, because of a cut. Even with gloves on and everything, I got stuck. I mean, it really cut. It managed to take whole pieces out of me, you know? (...). (...) I was cut once, a needle that perforated through (...) you don't know what was inside that syringe; 
Before, you would get stick by a syringe, or cut by some glass. And what did you do? "Ah, that's nothing!" You picked up a rag, wrapped it up like this, and away you go, and you went home and took care of it yourself. You didn't need to go taking leave from work. We get cut and we wash and clean it up ourselves; Several cases of car accidents where the collector jumps without looking and, all of a sudden, a car arrives and tosses him up in the air.

If you really observe, we are at risk, yes. But as they say, we have to take our own precautions to avoid the difficulties that would come from getting some sort of illness;

Infectious waste is full of everything. So you can have an accident and run the risk of getting hepatitis, understand? That's why they require us to keep all of our vaccines up to date, because of that. Because the risk is constant; Needle, contact with blood;

In what I do, there isn't any risk of an accident;

You have to keep pushing for everything to fit in. Everything has to fit in, because there's another client further on and if you show up and say "I don't have [a spare bin] you'll get a warning; You have to squeeze the rubbish in and that's not our job;

\section{Perception of work-} associated risks

\section{Comparison between domestic and healthcare} waste
There's a big risk of us being contaminated with some other person's sickness, you know. Let's say a drug addict, a guy shoots something up his arm and it's contaminated. So he uses it and throws it in the bin, doesn't cover the syringe or anything. He throws it away and then we can be collecting it and get stuck with that syringe;

As far as fooling around goes, horseplay. (...) He picked up the bag of slurry, which is this bag full of stinky water. So I saw him getting closer and I threw it over there (referring to the truck's compactor) and ran away. Right when the press was in action, dropping down. Right when he was about to throw it, it exploded all over him! (Critical situation of workers being exposed to liquid from solid waste - without thinking of the related health risks. They perceive it as a game, as a type of "baptism");

In hospital settings, it's still a little concerning even nowadays. Because even if you just knock this, splashes a little, or a little bit of water. There's a lot of bacteria there, and lots of other stuff; you have no idea what's in that rubbish. Because splash, even if you 're wearing a mask and everything, all of it will get in your eyes and everything. Because we work without glasses, without anything.

Rests of food, cups in the bin, it's recyclable. (...) I think there's less risk. For common waste, I think so; The infectious type is worse, for sure; It's worse, you have to be more careful, you know, when transporting it. Use the proper PPE to avoid getting contaminated;

Because often someone that is taking care of a serious wound, that is occupying a hospital bed while he could be taken care of at home, his rubbish goes into our rubbish (referring to the collection of household waste). But what happens is that that rubbish is mixed with the rubbish that we pick up

Big difference. Because in hospitals there is a lot of bacteria, I tell you. You work with gloves, a mask, besides all of the bacteria that you rub up against there with slurry and water flying around, and sometimes, splash; 
If we're talking about spreading viruses, certainly, because we and our colleagues are in direct contact with waste. You take a glove, you put it on (...). But here I've already touched some rubbish. I was in contact with bacteria. I do this to take it off. How do I take the other one off? You have to touch the glove and keep it in the truck. Here I'm already in direct contact (demonstrating that with his uncovered hand he will have to touch the part of the glove that was in contact with solid waste - proving that he does not know how to perform the process of taking off his glove without entering into contact and, moreover, explaining this to colleagues who agree with his presentation). And you have to take it and punch the rubbish in quite a bit. The bag may be full, full of air, it blows up and bursts. And it squirts all over us. And we get that all day long;

Hygiene habits

He works all day the way we do, and when the time comes to go home, he goes home and doesn't shower. It's not just harmful for him, it's harmful for his house. He's bringing home the contaminants;

If you think about contamination, we contaminate a lot of places. You go for a coffee and touch a disposable cup; then someone else picks it up too, our hand is infected. The bottle, you open the bottle;

The guy, with a glove on, picked up a sandwich with his glove. Are you kidding me? (...) If you take off the glove, you'd still have a lot of bacteria on your hand, because we work with rubbish, and even still you touch the food that you eat with that glove?

Smoking with the gloves on; They don't take their gloves off to smoke.

There's discrimination, you know? For being a scavenger. When, in truth, we aren't scavenger. We're gari (Brazilian word to describe formal workers that manage wastes);

Stigma of working with (...) some woman might give you water to drink, but she doesn't want the cup back. 'You can take the cup, you can take it, scavenger. You know? Right away, waste you understand

Rubbish is what a resident puts outside. Rubbish is what we throw in the truck. Not us! We aren't rubbish! We're street sweepers and it took time for society to start to realize that 
Each focus group presented particular characteristics throughout the respective discussions. The richness of the debate and the effective participation of the members demonstrated their need to be heard. Some participants expressed satisfaction with having had the chance to speak, to hear accounts from their fellow colleagues and, mainly, to be heard by a research team that was interested in understanding their reality. In that moment, I was no longer a simple cleaner, said one of the participants at the end of a focus group. The disparagement felt by these workers was made clear throughout the discussions. One participant even said that he could not complain much about his health problems to his employers, since whatever the company wants is my work, and if you don't do it, they'll find someone else (to do that work).

The focus groups commenced with questions on the importance of their work. Even if they work in inadequate conditions, according to the participants' observations, they demonstrated on several occasions that they were clearly conscious of the importance of their work. Remarks indicating this include: I think that it is a public utility service and the faster that we get rid of that waste, the level of hospital infection is much less. Even so, it was recognized that the work is considered 'tough' (or 'heavy' in Portuguese), due to the characteristics of their activities. Some people show up here and leave before lunch (referring to workers that resign the same day that they start the job). We're there and we run 45 kilometers a day, (...) up-hill and down-hill, understand? Down narrow streets. Between cars. (...) So what you get is a real heavy load on the worker's body, understand? And (...) the company doesn't provide any support, understand?

About the uniform worn by workers, part of the applicable PPE, different parts must be cleaned periodically. The discussion on this theme converged around the conclusion that 
uniforms are cleaned in workers' own households, including those individuals who collect healthcare waste. One participant commented: I wash it at home, but I wash and dry it separately. Regarding gloves, for example, I put them in a little bag that I keep inside my larger bag. Every day I take my gloves (...). But if they get dirty (...) [form contact with] waste water, then you have to throw them out.

When discussing about cuts, participants' remarks indicated that sharps containers, which are made out of cardboard, often do not guarantee effective protection, since generally the bottom [of the container] is sensitive. When you lift it up, it opens up. In general, you can't be sure [that it is safe]. The cardboard [referring to the recipient for sharps] doesn't sustain the weight of the needles (...) so it opens. And on the box it is written that it should be picked up by the handle. But if you pick it up by the handle, it will open up in your hand.

Regarding working conditions, the participants mentioned exposure to risks: (...) there was a mountain of rubbish that went from here to that car park [making reference to a distance of more than 100 meters]. I was almost fired because of it, because at the time I made a video of all the rubbish-it was raining, no less - the rubbish all wet, needles sticking out too. It was me and this guy here [referring to one of his colleagues in the focus group]. I went and said: this is no work for us to be doing! This isn't part of our duties! [tone of revolt owing to the type of work] (...) we aren't going to touch this!

An employer's expectations of good performance from workers can be stymied by workrelated accidents, which can lead workers to feeling uneasy about reporting such incidents. As long as you're doing well and are doing things right, (...) that's good, you're the best thing around. But if you say no or get sick, it's over. Two colleagues of ours were hurt working. They were hurt while working. They were both dismissed last week. 
Accounts were shared on the subject of waste being (...) heavy, I'm not going anywhere with this much rubbish. Then he said, 'if you don't start moving I'm going to have to switch you out'.

Regarding the reporting process of accidents, when the accident occurs, you have to go and report it, right? To see if you need to file a WAC (Work Accident Communication, "Comunicado de Acidente do Trabalho" in Portuguese). But, when it's just something small, you usually ignore it. It's just for serious accidents, really. Like if you break your arm or twist your ankle, when you really can't work. Some isolated remarks referred to recognizing workers' rights and the importance of reporting accidents, considering that further on in time, you may feel something, some side effects. Then what? If you didn't communicate it to the company (...) at the end of the day, it's you who loses. For any cut suffered by a waste collector, there is an immediate obligation to communicate it to his/her superiors.

On the subject of immunization, workers commented that usually you are asked for hepatitis, yellow fever and tetanus. Practically all companies will ask you for those three vaccines, they're the essentials. That's the rule. (...) some people are afraid of needles and will fib though, you know, and if they don't get their vaccine, they will return home [implying that the company will not hire the individual]. The previous account demonstrated that, in some cases, a company's authorities will deny employment to individuals that have not presented proof of immunization. On the other hand, some individuals admitted that they had not been immunized: They didn't verify my vaccination status because I'm just a temporary worker [replacing a regular employee on vacation].

When questioned about sick leave from work due to accidents, some of the participants alleged that they had reported "back problems", muscular lesions and depression. One 
worker commented: The main cause is the back problem, really. Everyone who took leave that I know had problems with their back.

About workplace training, they responded that from time to time, some training has to take place. Ours was, it's... [pause, confusion] it's like, from one [worker] to another. I started two weeks ago. I'm doing this for myself. Several participants recognized that training is important.

\section{Discussion}

Discussion section was divided according to the most remarkable themes regarding occupational health, as presented during focus groups and suggesting the participants' perception about these topics.

\section{The use of Personal Protective Equipment and perceptions on health and work- associated risks}

Participants' remarks indicated that lacking use of Personal Protective Equipment (PPE) can be associated with worker negligence, lack of adequate training and/or the poor quality of available equipment. The participants also indicated that the language used in training on worker safety was not appropriate and did not often lead to a change in their behavior. Some workers used PPE only because their employer required them to do so. It was noted that workers did not appropriate the concept of health protection in the context of their work duties. 
Because most of the time not wearing personal protection equipment did not lead to serious accidents, many waste workers did not adopt these equipment's. Dias, Machado \& Santos (2012) and Ferreira \& Anjos (2001) reported the same negligence context regarding PPE use. Similar to this study, Drach-Zahavy \& Somech (2010) demonstrate that nurses sometimes do the same, acknowledge the fallacy of these heuristics, and mistakenly perceived their implicit theories as correct.

About health perceptions at work, there were exceptional cases in which individuals said that they felt included and valued in their workplace and, for that reason, paid attention to the conditions that could affect their personal health in their activities as waste handlers. The feelings of recognition and value in their work were associated with the sense of belonging to the context that they are a part of. In turn, that leads to increased self-esteem among workers and, consequently, greater personal care for their own health. Oliveira (2007) commented similar context despite reported an unfavorable occupational situation in urban cleaning companies from a Brazilian city.

The main topic of discussions regarding work-related accidents was the risk of cuts due to the presence of sharp materials present in both domestic and healthcare waste. Disposal of solid waste in proper packaging was considered a prerequisite to reduce occupational risks. Containers for sharps are used mainly in healthcare settings to discard needles, syringes and other materials that could pose potential risks mainly to waste collectors. Work-related accidents involving sharps were also reported by Silva et al. (2014), Vieira, Padilha \& Pinheiro (2011), Velloso et al. (1997), Oliveira (2007) and Mol et al. (2016).

\section{Perspective regarding accidents suffered}


Work-related accidents were described as a part of the workers' routine tasks, something trivial and common, as outlined in TABLE 2, category "perspective on accidents suffered". Disregard for the use of PPE was referred to as a common reality among the participants. Cases were mentioned of colleagues contracting hepatitis, through accidents with infected sharps. Monitoring of worker health was described as inadequate due to limited ongoing support from employers in the case of accidents and evidence of lacking immunization against hepatitis B. Indeed, not all workers had been previously vaccinated before their exposure to waste.

A study of waste collectors found that, over time, workers reported worsening health conditions mainly due to muscular strain, which reduced their productivity and in some cases led to temporary or even permanent leave from work (i.e. workers either resigned or were dismissed). Often, support structures for workers are non-existent or limited to routine check-ups, for instance upon being hired or dismissed, or periodically. Psychological support is also often non-existent (Santos, Lima, Murta \& Motta, 2009).

For both groups of workers in this study, the presence of needles and other sharps in plastic bags - or simply on the ground - was frequently cited. Discussions were intense regarding the improper disposal of sharps. Particular emphasis was placed on the disregard of those who produce waste, as they often do not take care to ensure that sharps are disposed of in adequate conditions so as to protect waste collectors.

In accordance with TABLE 2, category "perspective on accidents suffered", accounts of accidents with sharps are considered the most common. Furthermore, improper disposal of waste was highlighted for both common and healthcare waste. Other accounts of workers in urban cleaning (Santos et al., 2009; Dias et al., 2012; Ferreira \& Anjos, 2001), also indicate that sharps are often discarded improperly in bags mixed with other solid 
waste. Another problem related to improper disposal of waste is that of overloading of the containers, making then far too heavy, which demands greater physical effort of the workers in their collection duties, as also related by Oliveira (2007) and Silva et al. (2014). A lack of accidents related to sharps was revealed in a study performed with health service workers in the United Kingdom, which indicated a frequent occurrence of non-notified accidents (Elder \& Paterson, 2006).

Most times, the workers demonstrated that they were powerless against the improper disposal of solid waste. They concluded that the waste could not remain where it was: it had to be collected. This situation manifested in both groups of workers. In the case of waste collectors in the health sector, inadequate management practices were revealed as improper disposal of waste indicated a lack of supervision in relation to this task.

As evidenced in TABLE 2, category "perspective on accidents suffered", accidents with cuts and sticks were reported as most common and often a part of workers' everyday routine. The absence of officially reported accidents was considered as a sign of inattention to workers' health. Workers often conveyed that accidents with sharps were a part of their work. In some cases, workers explained that they did not stop working after being stuck or cut, and would only care for their wounds upon returning home. It was apparent that not all participants understood that cuts and sticks are accidents. There was a perception among some workers that an accident is only an event that provokes the total incapacity of the worker to continue performing his/her duties. In this way, it was suggested that cuts occur frequently and are often not notified or reported. This extremely high account on the accidents reports related by participants is higher than all literature reports, as presented by Silva et al. (2014), Vieira, Padilha \& Pinheiro (2011), Velloso et al. (1997), Oliveira (2007), Domingo \& Nadal (2009), Rushton (2003). 
Workers' remarks on compliance with safety norms did not converge. One remark indicated that not all work-related accidents were registered regularly. On the other hand, at certain points in time, the participants attempted to change the focus of the discussion, suggesting that accidents have always been effectively reported. This perceived posturing can be understood as a sign of insecurity out of fear that the managers of the waste collectors in question would punish them for reporting that they had not complied with workplace safety norms. Moreover, different understandings of the concept of workrelated accidents were observed.

The concept developed in Law $n^{\circ} 8.213 / 91$ on work-related accidents is associated with any accident that provokes "bodily lesion or functional disruption causing death or loss or reduction — permanent or temporary—of one's ability to work". Thus, sticks and cuts are bodily lesions that can be associated with the risk of the worker contracting an infection by pathogenic substances if the sharp material has been in contact with contaminated biological materials.

Among professionals in nursing, Castro and Farias (2009) reported that the fear of accidents involving sharps was related, in most cases, to the possibility of infection by some type of pathology, mainly hepatitis or HIV. Accidents involving sharps with the presence of blood or other bodily liquids in nurses' everyday activities were reported as alarming, especially given the nurses' uncertainty as to the possible positive serology of the source of the biological material (Vieira et al., 2011; Dias et al., 2012; Özdelikara, 2012). Workers that collect domestic solid waste or healthcare waste are exposed to similar risks, but in different circumstances. 


\section{Worker immunization}

Immunization against hepatitis B and tetanus before exposure to solid waste are advisable health prevention measures for workers in this sector. Regarding hepatitis B immunization, the General Coordination of the National Immunization Programme (Coordenação Geral do Programa Nacional de Imunizações - CGPNI) and the National Programme for Prevention and Control of Viral Hepatitis (Programa Nacional para a Prevenção e o Controle das Hepatites Virais - PNHV) of the Ministry of Health, have made vaccination against HBV available since March 2010, through Brazil's Unified Health System (Sistema Único de Saúde - SUS) for several groups classified as vulnerable, regardless of age. These include workers who collect healthcare and domestic waste.

A specific norm exists for activities in healthcare settings, which includes a provision regarding the right to immunization. Regulatory Norm NR 32 concerns worker safety and health in healthcare services, and includes a specific provision on worker vaccination: "all workers providing healthcare services must be provided-at no charge-with immunization against tetanus, diphtheria, hepatitis B and those others established within the PCMSO" (Brasil, 2005). There is clear evidence in the literature that hepatitis B is more prevalent among waste collectors than in the general public (Corrao, Del Cimmuto, Marzuillo, Paparo \& La Torre, 2013; Tooher, Griffin, Shute \& Maddern, 2005; Luksamijarulkul et al., 2008).

Thus, it is the responsibility of employers to ensure effective immunization for workers performing waste collection, as a prerequisite before the worker commences work. 
Workers suggested that fellow waste collectors had been infected with hepatitis in the course of their duties. The discussion led the participants to reflect upon the actual risk of being exposed to infectious substances in the waste that they handle, which demonstrated the need for precaution mainly when handling sharp waste. Workers also commented on collecting waste containing blood without gloves, revealing another potentially infectious material to which workers are exposed. Other studies also found an association between hepatitis B infection and exposure to waste at work, as presented by Corrao et al. (2013), Luksamijarulkul et al. (2008), Mol et al. (2016) and Shiferaw et al. (2011).

Discussions with the workers revealed that immunization efforts did not always provide the assurances of cover protection, as provided by applicable norms. A serological study on waste collectors in Belo Horizonte (Minas Gerais, Brazil) indicated that only 252 of the 461 individuals assessed (54.7\% - 207 exposed to domestic waste and 45 exposed to healthcare waste) had been effectively vaccinated. It may be highlighted that $153(33.2 \%)$ workers exposed to domestic waste and $16(26.2 \%)$ workers exposed to healthcare waste reported that they had been involved in at least one accident with sharps. The number of accidents reported by workers was high in both groups (Mol et al., 2016).

\section{Negative health consequences originating from work with waste}

Participants alleged that they had reported "back problems", muscular lesions and depression, as more common sick leave from work. The accounts of workers agreed with information from historical databases of the social security services. The highest rate of benefit pay-out for domestic waste collectors is due to lesions, poisoning and other consequences of external causes $(25 \%)$, followed by problems with the skeletomuscular 
system and connective tissue (24\%) (Brasil, 2015). Accidents with sharps and muscular lesions, in addition to symptoms in the back, constituted the majority of the country's workplace accident reports for this category of workers. Another qualitative study found that urban cleaning workers presented indicators of early onset health deterioration. In the study, pain was reported in various parts of their bodies - especially in the extremities, knees, legs and spinal cord for $67 \%$ of participants - as well as chronic fatigue for $54 \%$ of participants (Santos et al., 2009).

TABLE 2 contains an account regarding exposure to liquids in solid waste under the category "perception of work-associated risks". The most critical moment for workers is while waste is being compacted in the truck, as per the remarks of workers in healthcare and domestic waste collection. Participants commented on the playful atmosphere among workers in which they purposefully create situations that expose the group to liquids in solid waste. Exposure to liquids in solid waste can entail negative impacts on health. If exposure to liquids occurs simultaneously with cuts (which are frequent according to workers' accounts), it may increase the chances of certain infections. Hepatitis B, for example, is present in bodily secretions and excreta, and it also presents environmental persistence. A very small dose of a substance infected with it is required for transmission to take place (Sattar, Tetro, Springthorpe \& Giulivi, 2001).

\section{Limitations}

This study represents an effort to understand more clearly the perceptions of waste workers about their labor activities and their association with health risks. There is information bias when participants discussed situations happened in the past. In 
particular, we understand there is a limitation in the sampling and recruitment process, due to poor adhesion (all interested participants were included that harmed sampling and representation and studied group).

\section{Final considerations}

The debate on risks to the health of workers exposed to solid waste, as captured through the technique of focus groups, allowed us to highlight participants' views of the aspects that they believed to require further reflection from all actors involved. Through the debate, several possible measures were suggested that, if adopted, could favor improved working conditions for those workers.

Consolidated preventive measures for worker health are considered urgent, including periodic certification for immunization against hepatitis B and tetanus for all workers as a prerequisite to initiating their activities. Furthermore, the research suggests that an inclusive atmosphere for workers to talk about their health is important in order to promote more effective work safety measures. Such measures include routine aspects, such as the proper use of PPE, as well as engaging in dialogue with workers on concepts that must be discussed and added into their daily activities.

The health-sickness process must be studied at greater length for workers in waste collection as, in the majority of countries — especially developing countries — this activity still involves a high degree of human exposure to waste. Regulation by the public authorities and effective social participation (of workers and the related managing entities) is essential for all aspects of urban cleaning services. Particular emphasis is 
needed for health promotion and preservation, improved working conditions and overcoming stigma.

Social control will be crucial to create opportunities for workers to participate in the processes of health promotion, in addition to genuinely valuing such workers and freeing them for further personal and professional development. 


\section{References}

Barbour, R. (2009). Grupos Focais [Focus groups]. FLICK U, editor. Porto Alegre: Artmed; 216p.

Bardin, L. (2008). Análise de conteúdo [Content analysis]. Lisboa: Edições Setenta; 281p.

Bauer, M.W.; Gaskell, G. (2007). Pesquisa qualitativa com texto, imagem e som - um manual prático [Qualitative research with text, image and sound - a practical manual]. 6 ed. Petrópolis, RJ: Editora Vozes.

Brasil. (1988). Constituição da República Federativa do Brasil [Constitution of the Federative Republic of Brazil]. Brasília - DF: Senado Federal: Centro Gráfico. p. 292.

Brasil. (2005). Norma Regulamentadora NR 32, de 11 de novembro de 2005 do Ministério do Trabalho e Emprego. Dispõe sobre a segurança no trabalho em serviços de saúde. [Ministry of Labor and Employment. Provides for work safety in health services] Diário Oficial da União, Brasília, 16 nov. Seção 01. p. 29.

Brasil. (2012). Ministério da Saúde. Diretrizes e normas regulamentadoras de pesquisas envolvendo seres humanos: resolução n. 466 de 12 de dezembro de 2012 [Ministry of Health. Regulatory guidelines and norms of research involving human beings] Retrieved from: http://conselho.saude.gov.br/resolucoes/2012/Reso466.pdf: Conselho Nacional de Saúde; [accessed: abr.2015].

Brasil. (2015). Aeps InfoLogo - Base de dados históricos da previdência social: Ministério da Previdência Social 2015 [Historical Social Security Database: Ministry of Social Security 2015] [Retrieved from: http://www3.dataprev.gov.br/infologo/inicio.htm]. 2015. Accessed: 23/09/2015]. 
Castro, M. R., Farias, S. N. P. (2009). Repercussões do acidente com perfurocortantes para a enfermagem: uma construção a partir do grupo focal [Repercussions of accident with perforating-cutting instruments for the nursing: a construction based on the focal group]. Esc Anna Nery. 13(3). 523-9. DOI: 10.1590/S1414-81452009000300010.

Corrao, C. R. N., Del Cimmuto, A., Marzuillo, C., Paparo, E., La Torre, G. (2013). Association between Waste Management and HBV among Solid Municipal Waste Workers: A Systematic Review and Meta-Analysis of Observational Studies. The Scientific World Journal. V. 5:692083. DOI: 10.1155/2013/692083.

Debus, M. (1988). Manual para excelência em la investigación mediante grupos focales [Manual for excellence in research through focus groups]. Pennsylvania: University of Pennsylvania; Applied Communications Technology, Needham Porter Novelli. DOI: 10.11606/issn.2176-7262.v45i1p12-22

Dias, M. A. C., Machado, A. A., Santos, B. M. O. (2012). Acidentes ocupacionais com exposição a material biológico: retrato de uma realidade [Occupational injury involving exposure tobiological fluids: a portrait of reality]. Revista da Faculdade de Medicina de Ribeirão Preto e do Hospital das Clínicas da FMRP. 45(1):12-22. DOI: 10.11606/issn.2176-7262.v45i1p12-22.

Domingo, J. L., Nadal, M. (2009). Domestic waste composting facilities: A review of human health risks. Environment International. (35) p. 382-9. DOI: 10.1016/j.envint.2008.07.004.

Drach-Zahavy, A., Somech, A. (2010). Implicit as Compared With Explicit Safety Procedures: The Experiences of Israeli Nurses. Qualitative Health Research. 20(10) 1406-1417. DOI: 10.1177/1049732310373256. 
Elder, A., Paterson, C. (2006). Sharps injuries in UK health care: a review of injury rates, viral transmission and potential efficacy of safety devices. Occupational Medicine. 56:566-74. DOI: 10.1093/occmed/kq1122.

Ferreira, J. A., Anjos, L. A. (2001). Aspectos de saúde coletiva e ocupacional associados à gestão dos resíduos sólidos municipais [Public and occupational health issues related to municipal solid waste management]. Cad Saúde Pública. 17(3):689-96. DOI: 10.1590/S0102-311X2001000300023.

Flick, U. (2009). Introdução à pesquisa qualitativa [Introduction to qualitative research]. 3 ed ed. Porto Alegre: Artmed; 405p.

Gaskell, G. (2007). Entrevistas individuais e grupais [Individual and group interviews]. In: Bauer MW, Gaskell Go, editors. Pesquisa qualitativa com texto, imagem e som: um manual prático. 6. ed ed. Petrópolis: Vozes; p. 64-89.

Gebbie, K., Merrill, J., Hwang, I., Gupta, M., Btoush, R., Wagner, M. (2002). Identifying Individual Competency in Emerging Areas of Practice: An Applied Approach. Qualitative Health Research. V. 12(7), pp. 990-999. DOI: 10.1177/104973202129120403

Ivey, J. (2011). Focus Groups - Demystifying Research. Pediatric Nursing. 37(5).

Krueger, R. A. (1998). Analyzing and reporting focus group results. Thousand Oaks, CA; Sage Publications.

Krueger, R. A. (2006). Analyzing focus group interviews. Journal of Wound, Ostomy and Continence Nursing. Spotlight on Research series (Summer). 
Lazzari, M. A., Reis, C. B. (2011). Os coletores de lixo urbano no município de Dourados (MS) e sua percepção sobre os riscos biológicos em seu processo de trabalho [The perception of urban garbage collectors of Dourados, in the state of Mato Grosso do Sul, regarding the biological risks involved in their work routine]. Ciência \& Saúde Coletiva. 16(8):3437-42. DOI: 10.1590/S1413-81232011000900011.

Luksamijarulkul, P., Sujirarat, D., Charupoonphol, P. (2008). Risk behaviors, occupational risk and seroprevalence of hepatitis B and A infections among public cleansing workers of Bangkok Metropolis. Hepatitis Monthly. 8(1):35-40.

Mol, M. P. G., Gonçalves, J. P., Silva, E. A., Scarponi, C. F. O., Greco, D. B., Carincross, S., Heller, L. (2016). Seroprevalence of hepatitis B and C among domestic and healthcare waste handlers in Belo Horizonte, Brazil. Waste Management \& Research. DOI: $10.1177 / 0734242 X 16649686$

Oliveira, M. G. (2007). Características organizacionais e acidentes ocupacionais em empresas de limpeza urbana em Salvador-BA [Organizational characteristics and occupational accidents in urban cleaning companies in Salvador-BA]. Tese (doutorado) - Instituto de Saúde Coletiva. Salvador: Universidade Federal da Bahia.

Özdelikara, A., Tan, M. (2012). Conditions in which nurses are exposed to the hepatitis viruses and precautions taken for prevention. Australian Journal of Advanced Nursing. 30(1):33(9).

Powell, R. A., Single, M. H. (1996). Focus Groups. International Journal for Quality in Health Care. 8(5):499-504. DOI: 10.1093/intqhe/8.5.499. 
Rushton, L. (2003). Health hazards and waste management. British Medical Bulletin. 68:183-97. DOI: 10.1093/bmb/ldg034.

Santos, M. C. O., Lima, F. P. A., Murta, E. P., Motta, G. M. V. (2009). Desregulamentação do trabalho e desregulação da atividade: o caso da terceirização da limpeza urbana e o trabalho dos garis [Work deregulation and deregulation of the activity: the case of outsourcing of urban cleaning and the street sweeper work]. Produção. 19(1):202-13. DOI: 10.1590/S0103-65132009000100013.

Sattar, S. A., Tetro, J., Springthorpe, V. S., Giulivi, A. (2001). Preventing the spread of hepatitis B and C viruses: Where are germicides relevant? American Journal of Infection Control. 29:187-97. DOI: 10.1067/mic.2001.114233.

Shiferaw, Y., Abebe, T., Mihret, A. (2011). Hepatitis B virus infection among medical waste handlers in Addis Ababa, Ethiopia. BMC Research Notes 4: 479. DOI: 10.1186/1756-0500-4-479.

Silva, D. F., Sperling, E. V., Barros, R. T. V. (2014). Avaliação do gerenciamento dos resíduos de serviços de saúde em municípios da região metropolitana de Belo Horizonte (Brasil) [Evaluation of health care wastes management in the metropolitan region of Belo Horizonte (Brazil)]. Engenharia Sanitária e Ambiental. 19(3):251-62. DOI: 10.1590/S1413-41522014019000000452.

Stehling, M. M. C. T. (2013). Estudo sobre riscos ocupacionais, biológicos e químicos, em laboratórios de uma universidade pública brasileira, 2012-2013 [Study on occupational, biological and chemical risks in laboratories of a Brazilian public university, 2012-2013]. Tese de Doutorado em Ciência Animal: Epidemiologia. Escola de Veterinária - UFMG. Belo Horizonte - MG. 
Tarantola, A., Abiteboul, D., Rachline, A. (2006). Infection risks following accidental exposure to blood or body fluids in health care workers: A review of pathogens transmitted in published cases. Am J Infect Control. 34(6):367-75. DOI: 10.1016/j.ajic.2004.11.011.

Thomas, C. (2000). Dicionário Médico Enciclopédico [Encyclopedic Medical Dictionary]. 17. Ed ed. São Paulo: Manole.

Tooher, R., Griffin, T., Shute, E., Maddern, G. (2005). Vaccinations for waste-handling workers. A review of the literature. Waste Manage Res. 23(1):79-86. DOI: $10.1177 / 0734242 X 05048037$.

Velloso, M. P., Santos, E. M., Anjos, L. A. (1997). Processo de trabalho e acidentes de trabalho em coletores de lixo domiciliar na cidade do Rio de Janeiro, Brasil [The labor process and work-related accidents among garbage collectors in Rio de Janeiro, Brazil]. Cad Saúde Públ. 13 (4):693-700. DOI: 10.1590/S0102-311X1997000400012.

Vieira, M., Padilha, M. I., Pinheiro, R. D. C. (2011). Análise dos acidentes com material biológico em trabalhadores da saúde [Analysis of Accidents with Organic Material in Health Workers]. Rev Latino-Am Enfermagem. 19(2).

Worthen, B. R., Sanders, J. R., Fitzpatrick JL. (2004). Avaliação de Programas: concepções e práticas [Program Evaluation: conceptions and practices]. São Paulo: Editora Gente. 